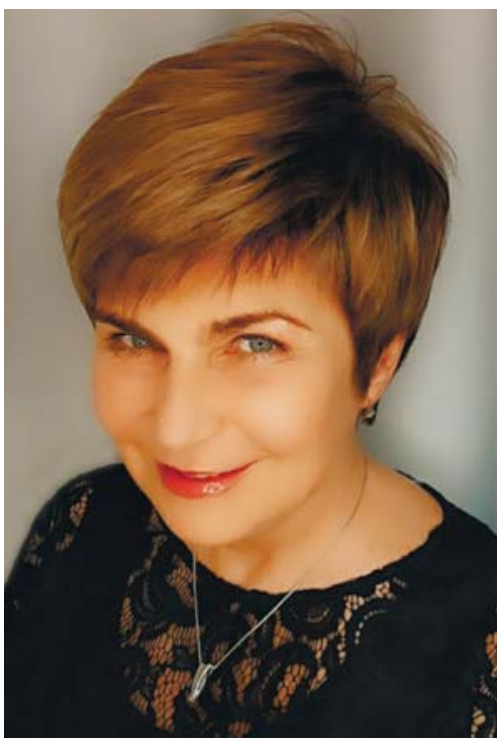

ПРІХНА

Тетяна Олексіївна академік НАН України, завідувач відділу технологій високих тисків, функціональних керамічних композитів та дисперсних надтвердих матеріалів Інституту надтвердих матеріалів ім. В.М. Бакуля НАН України

\section{ПРО РОЗВИТОК МІЖНАРОДНОГО СПІВРОБІТНИЦТВА В НАН УКРАЇНИ}

Шановні члени Національної академії!

Шановні присутні!

У своїй звітній доповіді президент НАН України академік Анатолій Глібович Загородній підкреслив важливість міжнародного співробітництва та робіт, що виконуються за міжнародними грантами і проєктами. Цілком зрозуміло, що створення сучасних технологій виробництва, вирішення завдань математики, фізики, хімії, астрономії, економіки, медицини, соціології, біології, філософії та інших наукових галузей потребують тісного співробітництва не лише між науковцями України, а й між ученими всього світу.

Безсумнівно, що одними з найбільш рейтингових вважаються проєкти нової рамкової програми ЄС на 2021-2027 pp. «Горизонт Європа» (European Union Framework Programme for Research and Innovation "Horizon Europe"), програми Свратом на 2021-2025 pp. (EURATOM Research and Training Programme), програми НАTO «Наука заради миру» (NATO Science for Peace) та ін.

Ключовими пріоритетами програми «Горизонт Європа» $€$ здоров'я людини, охорона навколишнього середовища та електроніка. У цій програмі, на відміну від попередніх, немає окремого напряму з матеріалознавства, але конкурси, пов'язані з матеріалознавством, можна знайти в робочих програмах пріоритетного напряму «Цифрові технології, промисловість та космічний простір» (Digital, Industry and Space).

Сподіваємося, що найближчим часом Україна завершить технічні перемовини з представниками Сврокомісії, підпише та ратифікує договір про асоціацію з програмою «Горизонт $\mathrm{CB}_{\mathrm{B}}$ ропа» і тоді матиме можливість брати участь у цій програмі як асоційована країна. Це дуже важливо, оскільки на початку літа буде оголошено нові конкурси цієї програми на 2021-2023 рр. Хоча і зараз українські науковці можуть подавати проєктні пропозиції на вже оголошені конкурси цієї програми, а також використовувати можливості проєкту FIT-4-NMP, бенефіціаром 
якого є НАН України. Цей проєкт спрямовано на збільшення участі талановитих новачків, що проводять дослідження в галузі нанотехнологій, новітніх матеріалів та передових виробничих процесів, у проєктах програми «Горизонт Європа», а її потужний міжнародний консорціум здійснюе консультації з пошуку відповідних конкурсів та наукових контактів для підготовки і подання проєктних заявок.

Слід також відзначити надзвичайну важливість для України проєктів програми НАТО «Наука заради миру». Вони передбачають фінансування придбання високовартісного обладнання, участі у конференціях, організацію наукових форумів, стажування за кордоном та надання стипендій молодим ученим. I я хочу від імені грантоотримувачів проєктів програми «Наука заради миру» подякувати Анатолію Глібовичу Загородньому і Вячеславу Леонідовичу Богданову та всім дотичним до цього співробітникам Академії за те, що цього року Національною академією наук було започатковано фінансову підтримку таких проєктів, оскільки заробітна плата для виконавців у них не передбачена. Я вже вдруге поспіль є співкерівником проєктів цієї програми, в рамках яких займаюся розробленням ударостійких керамічних матеріалів та ультрависокотемпературних матеріалів для надзвукових літаків та інших застосувань. Національна академія наук і раніше підтримувала проєкти програми НАТО «Наука заради миру», але вибірково, на основі особистих звернень. Вважаю, що президент Академії повною мірою виконав свою передвиборну обіцянку, про що минулого року говорив як про справу честі. Сподіваємося, що в майбутньому підтримка таких проєктів стане ще відчутнішою.

Як член Національного агентства із забезпечення якості вищої освіти знаю, що при акредитації освітніх програм і особливо програм $\mathrm{PhD}$ велику увагу приділяють мобільності студентів, закордонним зв’язкам студентів і викладачів, їх участі у міжнародних конференціях і семінарах, публікаціям у високорейтингових журналах. Організації, що виконують проєкти за програмами ERASMUS, Copernicus, COST, у яких, до речі, можуть брати і беруть участь установи Академії, як правило, при проходженні акредитації повною мірою задовольняють усім вимогам оцінювання за переліченими вище критеріями.

Національний фонд досліджень України, до складу Наукової ради якого я також входжу, цього року планує фінансування двосторонніх проєктів з Німеччиною, виграних два роки тому, а також оголошення конкурсів за програмами міжнародного співробітництва з Францією, що дають змогу організовувати закордонні відрядження лише для молодих учених (до 10 проєктів), Японією (це всього 1-2 проєкти на 2 роки) та Польщею (до 10 проєктів). Втім, на жаль, кількість таких двосторонніх проєктів буде дуже малою. Зі свого досвіду знаю, що і невеликі двосторонні проєкти (у мене їх було понад 20) дозволяють значною мірою підтримувати зацікавленість закордонних і особливо європейських партнерів у проведенні спільних досліджень, мати доступ до найпередовішого обладнання i, що найголовніше, не сприяють відтоку наукової молоді, допомагають у пошуку партнерів для подання проєктів за такими програмами, як «Горизонт Європа», «Наука заради миру» тощо.

Тому, на мій погляд, перспективним для НАН України було б створення спільних двосторонніх наукових програм між Академією і організаціями на зразок BMBF (Німеччина), CNRS (Франція), організацією з міжнародного співробітництва OeAD (Австрія) та ін., тим більше, що законодавство України це дозволяє.

Як приклад дуже вдалого співробітництва 3 BMBF хочу навести проєкт UKRATOP, який уже четвертий рік поспіль виконує Київський академічний університет (керівник проєкту директор університету О.А. Кордюк, обраний учора академіком НАН України). В рамках цього проєкту десятки українських студентів, аспірантів і постдоків уже пройшли стажування і працювали протягом пів року, року чи півтора в Інституті твердого тіла та матеріалознавства ім. Лейбніца у м. Дрезден, Німеччина (Leibniz Institute for Solid State and Materials Research Dresden - IFW), директора яко- 
го Бернда Бюхнера (Prof. Dr. Bernd Büchner) було також обрано вчора іноземним членом нашої Академії.

Великий інтерес до співробітництва 3 науковцями України останнім часом виявляє Китай, який витрачає великі кошти на фінансування нових високотехнологічних розробок, але переважна більшість китайських проєктів усе ж спрямовані на те, щоб українські науковці працювали в Китаї, а спільні розробки ставали власністю цієї країни.

Наша держава опікується оновленням наукового обладнання та забезпеченням сталого соціально-економічного розвитку України, розвитку науки, про що свідчить нещодавно схвалена Урядом і затверджена Кабінетом Мiністрів України концепція Державної цільової програми розвитку дослідницьких інфраструктур в Україні на період до 2026 р., одним з результатів якої має бути створення та функціонування щонайменше 50 центрів колективного користування обладнанням, 9 державних ключових лабораторій і 3 національних наукових центрів.

МОН України ініціювало громадське обговорення порядку надання державної підтримки в рамках міжнародної європейської інноваційної науково-технічної програми EURECA, основною метою якої є підвищення рівня конкурентоспроможності Свропи через сприяння інноваційному підприємництву і партнерству між малими та великими підприємствами, науково-дослідними інститутами та університетами.

Національний фонд досліджень України планує провести цього року конкурс, спрямований на придбання високовартісного наукового обладнання вартістю до 30 млн грн.

Однак реальну можливість вигравати такі конкурси, як і конкурси міжнародних проєктів, матимуть науковці з високими наукоме- тричними показниками. А найвищі показники в Україні, як правило, мають учені, які досить тривалий час працювали в університетах і наукових установах Свропи та/або США. Проте навіть у високорозвинених країнах важко знайти університет чи лабораторію, які б були забезпечені всім необхідним обладнанням, наприклад для всебічного дослідження надпровідних матеріалів. Тому кооперація і спільні міжнародні дослідження є невід’ємною рисою сучасної науки.

Тенденція до «відкритої науки» передбачає публікації у відкритих наукових виданнях, що потребує значних коштів. Доступ до опублікування матеріалів у високорейтингових журналах, що входять до баз Scopus та Web of Science і мають, зокрема, квартилі Q1 і Q2, спрощується, якщо публікація є результатом доповіді на міжнародній конференції. Тому дозвіл на витрачання бюджетних коштів, що виділяються в рамках базового фінансування, на публікації статей чи книжок, а також збільшення коштів, призначених для забезпечення участі у міжнародних конференціях і семінарах, закордонних відряджень, у кінцевому підсумку сприятиме підвищенню рейтингу українських науковців, розширенню їх участі у міжнародних та національних проєктах, залученню більшої кількості грантів, що виконуватимуться на території України, дозволить придбати нове обладнання чи принаймні модернізувати старе, поповнити приладами центри колективного користування і розширити наукову співпрацю з іноземними закладами вищої освіти, науковими установами, тобто посилити інтеграцію України у європейський та світовий дослідницький простір і зменшити відплив наукової молоді.

На завершення свого виступу пропоную схвалити звітну доповідь президента НАН України Анатолія Глібовича Загороднього. Дякую за увагу! 